В силу исторических, архитектурных и ландшафтно-климатических условий перенос и кардинальная перепланировка кампуса САФУ им. М. В. Ломоносова не представляется возможной. Поставленная таким образом задача унификации и имиджевого объединения разрозненных учебных корпусов университета представляется очень сложной, но может быть решена через единое ландшафтное оформление кампуса. Оптимальная организация пространства предусматривает использование исходных природных особенностей местности и социально-культурный анализ территории. Унифицированное озеленение объединяет университетский кампус в единый ландшафтно-архитектурный комплекс. В сочетании с малыми архитектурными формами, которые поддерживают основной замысел, оно позволяет создать уникальный образ, поддерживающий имидж учебного заведения и идентичность региона.

\title{
***
}

1. Витюк, Е.Ю. Концепция формирования комфортной городской среды как средство выявления идентичности [Электронный ресурс] //Архитектон: известия вузов. - 2020. - №3(71). - Режим доступа: http://archvuz.ru/2020_3/4/, свободный (дата обращения: 21.12.2020). - Загл. с экрана.

2. Ендовицкая, А.Г. Студенческий кампус: инфраструктура безопасности [Электронный ресурс] // Организация работы с молодежью - 2017. - №1. - Режим доступа: http://ovv.esrae.ru/275-1211, свободный (дата обращения: 21.12.2020). - Загл. с экрана.

3. Палей, Е.С. Озелененное общественное пространство в композиции современных университетских кампусов Европы [Электронный ресурс] / Е.С. Палей // Academia. Архитектура и строительство - 2017 . - №4. - С. 55-62. - Режим доступа: http://www.raasn.ru/public/academia_2017_4.pdf, свободный (дата обращения: 21.12.2020). - Загл. с экрана.

4. Пучков, М.В. Архитектурная идентичность организации: пространственные схемы кампусов [Электронный ресурс] //Архитектон: известия вузов. - 2012. - №2(38). - Режим доступа: http://archvuz.ru/2012_2/3 ], свободный (дата обращения: 21.12.2020). - Загл. с экрана.

5. Чичикина, М. А. Кампусы университетов // Молодежь и наука: сборник материалов Х Юбилейной Всероссийской научно-технической конференции студентов, аспирантов и молодых ученых с международным участием, посвященной 80-летию образования Красноярского края [Электронный pecypc]. - Красноярск: Сибирский федеральный ун-т, 2014. — Режим доступа: http://conf.sfukras.ru/sites/mn2014/directions.html, свободный (дата обращения: 21.12.2020). - Загл. с экрана.

\section{Кукарина Е.Е. \\ Применения бентонитовых матов в качестве гидроизоляционных материалов в строительстве}

Самарский государственный технический университет (Россия, Самара)

doi: $10.18411 / 1 j-02-2021-48$

idsp: ljournal-02-2021-48

\section{Аннотация}

Современные тенденции строительства в крупных городах и мегаполисах, недостаток свободных земель, рост цен на землю и необходимость ее рационального использования приводят к активному освоению подземного пространства. Строительство подземных гаражей, паркингов, торговых центров, пешеходных переходов и транспортных тоннелей требует применение надежной (водоупорной) и долговечной гидроизоляции

Бентонитовые плиты широко используются в строительстве, например, при гидроизоляции. Материал в ходу довольно давно, ведь основным его компонентом является глина. Одна из знаменитых и уже устаревших разновидностей материала встречается под названием «Глиняный замок». Он представляет собой утрамбованное перемятое в плиту сырье, толщина которой составляла 30-40 см. Сегодня технологии 
шагнули далеко вперед, вобрав в себя все лучшее от старых технологий и современных наработок. Так появились бентонитовые маты, о которых пойдет речь далее.

Ключевые слова: бентонитовые плиты, глина, гидроизоляция, глиняный замок, водоупор, плотность

\section{Abstract}

Modern trends in construction in large cities and megacities, lack of available land, rising land prices and the need for its rational use lead to the active development of underground space. Construction of underground garages, Parking lots, shopping centers, pedestrian crossings and transport tunnels requires the use of reliable (waterproof) and durable waterproofing Bentonite slabs are widely used in construction, for example, in waterproofing. The material has been in use for a long time, because its main component is clay. One of the famous and already outdated varieties of material is found under the name "clay castle". It is a compacted paremata in plate raw material, whose thickness was $30-40 \mathrm{~cm}$ Today, technology has leaped forward, incorporating the best of old techniques and modern developments. So there were bentonite mats, which will be discussed further.

Keywords: bentonite plates, clay, waterproofing, clay lock, water resistance, density

Бентонитовые маты - это геосинтетические гидроизоляционные материалы рулонного типа, разработанные на основе природной бентонитовой глины. Быстро поглощают влагу и надежно удерживают ее. Материал используется для горизонтальной и вертикальной гидроизоляции подземных и заглубленных частей зданий и сооружений, а также в качестве противофильтрационных экранов - защитного слоя от попадания в почву и грунтовые воды загрязняющих веществ [7].

Бентонитовые маты обладают высокими гидроизоляционными свойствами, прочностью, устойчивостью к повреждениям и гибкостью на протяжении всего периода эксплуатации в любых гидрогеологических условиях.

Особенности, такие гидроизоляционные материалы чаще всего называют бентонитовыми матами из-за их визуальной схожести с этим природным материалом. С технической точки зрения, эта технология позволила существенно продлить срок службы той части сооружения, которая находится ниже нулевого уровня. В старые времена этот самый «глиняный замок» защищал помещения и конструкции не только от внешней влаги, такой как грунтовые воды и дожди с дополнительной влагой, но и как защиту внешней среды от внутреннего воздействия. Широкое применение это сырье нашло и в индустриальную эпоху, когда проблемы, связанные с утечками разных жидкостей, стали гораздо более обширными. Современные технологии несколько модернизировали этот материал, дав ему возможность увеличить и приумножить свойства «глиняного замка», сделав его простым в укладке. Качественную продукцию производят бренды Voltex и Bentofix NSP 4900. Инструкция их использования достаточно широка.

Бетониты очень нетоксичны, потому наименее вредны для окружающей среды. Среди гидроизоляционных материалов в этом плане с ними сравнятся только цементные плиты, но у них свойства гидроизоляции заметно хуже, нежели у бентонитовых.

Одно из важнейших условий для лучшей гидроизоляции - плотность прилегания. Чем плотнее бентонитовая плита прилегает к бетону, тем лучше получится гидроизоляция [4].

В качестве примера можно привести отечественные бентонитовые маты производителя «Водоупор». Данный продукт является рулонным геотекстильным, состоит из слоя синтетического полотна с обеих сторон, между которыми 
расположился слой бентонитовой глины (в гранулах). Крепятся слои по принципу иглопробивания.

Применение бентонитовых матов:

1. Строительство водоемов.

2. Гидроизоляция тоннелей, фундаментов, потолков подземных сооружений - подвалов, бункеров.

3. Для защиты как грунтовых вод, так и от них.

4. Гидроизоляция водных объектов (каналы, дамбы, водные хранилища, водные резервуары).

5. Гидроизоляция специальных жидкостей (нефтехранилища, промышленные отходы).

Среди достоинств бентонитовых матов можно подчеркнуть отсутствие дефектов или иных проблем, связанных с перепадами температур, экологическую безопасность. Если мат получил механическое повреждение, то он не теряет своих свойств. Если бетонная конструкция, к которой он прикреплен, получила повреждения механического характера, то бентонитовый мат также не теряет своих свойств и продолжает хорошо гидроизолировать данный участок. Продукт весьма долговечен и неограничен в цикле прихода и убывания влаги. Так же, как и многие современные технологические материалы, бентонитовые маты не требуют для укладки каких-то определенных инструментов или специального оборудования, а также весьма оперативны в укладке. Погода не влияет ни на скорость укладки, ни на качество самого материала. Сохраняют свою эластичность же вплоть до -35 градусов по цельсию. Стоит отметить и устойчивость бентонитового сырья к специальным растворам, нефтепродуктам или химическим веществам. Более подробно о том, какие вещества выдерживает данный гидроизоляционный материал, лучше поинтересоваться у производителя, чтобы подобрать идеальный вариант. Но бентонитовые маты выдерживают угрозы внешней среды, не теряя при этом своих свойств.

Монтаж гидроизоляционных материалов, в частности, бентонитовых матов, весьма прост. Для их монтажа необходима как можно более отчищенная поверхность бетона от грязи и мусора, а также сколов самого бетона. Желательно, чтобы при монтаже самим работникам не мешали на площадке. Как правило, такие работы выполняются бригадой из пяти человек с отдельным руководителем, который контролирует процесс выполнения работы со стороны [5-6].

Основной фронт работы этой бригады сводится к подготовке бетонного основания, а также стен, ведь необходимо делать определенный нахлест, чтобы улучшить свойства гидроизоляционного материала. Для сооружений, целиком скрытых под землей, гидроизоляция проводится со всех сторон, дабы избежать протечек и разрушения самой конструкции. Когда поверхность подготовлена, то маты выкладываются на выравнивающую стяжку. При этом для лучшей гидроизоляции процедура проводится внахлест, но не закрепляется. Швы же бентонитовых плит обрабатываются бентонитовыми гранулами, но зачастую просто гранулами обсыпаются такие моменты. На вертикальные же поверхности эти маты крепятся к стене специальными металлическими дюбелями внахлест. После чего бентонитовые гранулы мешаются до консистенции сметаны и ими обрабатываются швы покрытия. В случае такого типа гидроизоляции, ее необходимо заливать бетоном или же делать их засыпку. В воде смонтировать бентонитовые изделия также невозможно, они начинают слишком набухать.

Ошибки при монтаже: пожалуй, главной проблемой при гидроизоляционных работах, особенно в России, является тот факт, что заказчик зачастую ждет гораздо большего эффекта и качества от гидроизоляции, чем тот, который можно осуществить. 
Самыми частыми причинами некачественной работы по любой гидроизоляции являются неправильно подобранные материалы: самые дешевые и несовместимые друг с другом. Одной из причин может являться некачественная заделка швов. Но все-таки основной причиной является некорректное выставление сроков, которое зачастую идет по самой нижней временной границе, но встречается и такое, что заказчик решает, вопреки СниПам, сократить сроки по своему желанию, что является нарушением технологии. Порой, трудно объяснить, что любые материалы или иное сырье должны выдерживаться какой-то определенный срок [2]. Помимо заказчика, частенько и проектный отдел некорректно рассчитывает многие факторы, такие как разбухание самой бентонитовой смеси: не оставляют полостей для расширения материала, а это ведет к его деформации и потери его свойств. Иногда бывает, что полость слишком большая и это тоже вызывает дефект, так как свободные полости, куда бентонитовый материал не проникает даже после разбухания, остаются без гидроизоляции и это ведет к определенным последствиям. Важно, что при гидроизоляции бентонитовыми плитами необязательно выжидать 28 суток отстаивания бетона, но 10-12 дней на это дело отвести следует. К сожалению, нередки случаи, когда этот момент не учитывают ни проектировщики, ни заказчики.

При разработке и производстве работ есть определенные распространенные ошибки. Иногда нет достаточной информации об уровне грунтовых вод, их поднятии и уменьшения, а это немаловажный факт, так как высоту гидроизоляции высчитывают, опираясь и на эту величину. Еще одна распространенная ошибка - специальные выравнивающие растворы или бетонные стяжки, которые фильтруют воду. Некоторые подрядчики искренне уверены в том, что эта стяжка и бентонитовые плиты будут работать как одно целое, но ошибка заключается в том, что у гидроизоляции и стяжки совершенно разное назначение.

Вывод:

Бентонитовый мат является универсальным средством для гидроизоляции, имеющий минеральную основу. Благодаря своим свойствам, при условии качественного монтажа, является отличным материалом для гидроизоляции, защищающей сооружение не только от влаги, но и от газов. Является очень износостойким, а также прекрасно герметизирует сооружение, а сама конструкция бентонитового мата защищает от механических воздействий сердцевину сырья.

$$
* * *
$$

1. Гилязидинова Н.В. и др. Технологические процессы в строительстве: курс лекций: электронное учебное пособие [Электронный ресурс] для студентов направления подготовки 08.03.01 «Строительство». Кемерово: КузГТУ, 2016. С. 114.

2. Данилов Н.Н. и Терентьев О.М. Технология строительных процессов. М.: Высшая школа, 2000. С. 214

3. Хамзин С.Н., Карасев А.Н. Технология строительного производства. Курсовое и дипломное проектирование. М.: Высшая школа, 1984.

4. Зайков Д. Н. Новое поколение российских гидроизоляционных материалов проникающего действия // Строительные материалы, № 12, 2003, С. 20-21.

5. Технологии гидроизоляции зданий и сооружений // Промышленно-строительное обозрение, № 2 (100), 2007, С. 60.

6. Искрин В.С. и др. Гидроизоляция ограждающих конструкций промышленных и гражданских сооружений. Стройиздат, 1975. С. 215

7. Кирсанов Н.В. Генетические типы и закономерности распространения месторождений бентонитов в СССР / Н.В. Кирсанов, М.А. Ратеев, А.А. Сабитов и др. - М.: Недра, 1981, С. 214.

8. Котельников Д.Д. Глинистые минералы осадочных горных пород / Д.Д. Котельников, А.И. Конюхов, - М.: Недра, 1986, С. 247. 